\title{
PERSPEKTIF ORANG TUA TERHADAP ANAK BERKEBUTUHAN KHUSUS DI SEKOLAH INKLUSIF
}

\author{
Jesslin \\ Fakultas Psikologi, Universitas Indonesia \\ Jesslin1608@gmail.com \\ Farida Kurniawati \\ Fakultas Psikologi, Universitas Indonesia \\ farida1@ui.ac.id
}

\begin{abstract}
Abstrak
Perspektif adalah cara berpikir dan sikap tertentu tentang sesuatu, kemampuan untuk berpikir tentang masalah dan keputusan dengan cara yang masuk akal tanpa membesar-besarkan minat mereka, dalam penelitian ini yaitu tentang Anak Berkebutuhan Khusus (ABK) di sekolah inklusif. Tujuan dari penelitian ini adalah untuk mengetahui perspektif orang tua terhadap ABK di sekolah inklusif. Metode penelitian yang digunakan adalah melalui tinjauan literatur sistematis dengan menggunakan artikel yang diperoleh secara online dari 2 database, yaitu Scopus, dan Taylor \& Francis Online. Terdapat 9 artikel yang memenuhi kriteria dan hasil studi literatur sistematis ini menunjukkan bahwa secara umum orang tua memiliki perspektif positif dan mendukung keberadaan sekolah inklusif. Meskipun demikian, orang tua juga memperhatikan beberapa hal dalam proses penerapan pendidikan inklusif yang dikelompokkan ke dalam empat tema utama, yaitu sekolah, komunitas, pemerintah, dan keluarga. Tema-tema ini mewakili keprihatinan, keprihatinan, pengalaman, dan saran orang tua selama berselisih dengan Anak Berkebutuhan Khusus di sekolah inklusif.
\end{abstract}

Kata Kunci: Perspektif orang tua, kebutuhan khusus, pendidikan inklusi

\section{Abstract}

Perspective is a way of thinking and certain attitudes about something, the ability to think about problems and a decision in a way that makes sense without exaggerating their interests, in this research that is about Children with Special Needs (ABK) in inclusive schools. The purpose of this study was to determine the perspectives of parents towards ABK in inclusive schools. The research method used is through a systematic literature review using articles obtained online from 2 databases, namely Scopus, and Taylor \& Francis Online. There are 9 articles that meet the criteria and the results of this systematic literature study show that in general parents have a positive perspective and support the existence of inclusive schools. Nevertheless, parents also pay attention to several things in the process of implementing inclusive education which is grouped into four major themes, namely school, community, government, and family. These themes represent the concerns, concerns, experiences, and suggestions of parents during disputing Children with Special Needs in inclusive schools.

Keywords : parent perspectives, disability, inclusive education 


\section{PENDAHULUAN}

Pendidikan inklusif menjadi salah satu prioritas tertinggi dalam kebijakan pendidikan di banyak negara sejak adanya Pernyataan Salamanca UNESCO pada tahun 1994. Pendidikan inklusif diselenggarakan untuk memberikan kesempatan kepada semua peserta didik, yaitu bagi Anak Berkebutuhan Khusus (ABK), anak dengan potensi kecerdasan dan/atau bakat istimewa untuk mengikuti pendidikan atau pembelajaran dalam lingkungan pendidikan di sekolah reguler bersama-sama dengan peserta didik regular. Anak Berkebutuhan Khusus yang dimaksud dalam Permendiknas No. 70 tahun 2009 pasal 3 ayat 2, yaitu : tunanetra, tunarungu, tunawicara, tunagrahita, tunadaksa, tunalaras, berkesulitan belajar, lamban belajar, autis, memiliki gangguan motorik, menjadi korban penyalahgunaan narkoba, obat terlarang, dan zat adiktif lainnya, memiliki kelainan lainnya, dan tunaganda.

Terdapat banyak penelitian yang membuktikan bahwa ABK yang belajar di sekolah inklusif menunjukkan perkembangan yang lebih baik dalam keterampilan sosial dan interaksi dengan anak reguler yang akan membantu mereka untuk masuk ke dalam komunitas sosial di masa dewasa (Wiener \& Tardif, 2004). Hamilton (2013) dalam penelitiannya bersama dengan University of Denver juga menyatakan banyak anak dengan gangguan pendengaran berkembang dalam kemampuan bicara dan bahasa saat mereka diperlengkapi oleh alat bantu dengar dan memperoleh pengalaman belajar di kelas pra-sekolah secara normal. Kemampuan bicara dan bahasa juga meningkat saat mereka ditempatkan di lingkungan yang kaya akan bahasa dimana guru juga terdorong untuk merencanakan tambahan seorang terapis wicara. Para peneliti lain menyarankan ABK untuk belajar di sekolah inklusif untuk memperoleh manfaat akademis dari standar akademik yang lebih tinggi dan interaksi dengan siswa dengan kemampuan yang lebih tinggi di sekolah umum (Ruijis, Peetsma, \& van der Veen, 2010).

Meskipun terdapat banyak penelitian yang menyatakan banyak manfaat yang didapat dari pendidikan inklusif, namun banyak juga perdebatan mengenai bagaimana mengimplementasikan pendidikan inklusif, mengingat bahwa pendidikan inklusif merupakan konsep yang kompleks (Lindsay, 2003). Masalah yang ditemukan di sekolah inklusif lebih kompleks dibandingkan dengan sekolah pada umumnya. Berbagai tantangan yang dihadapi di sekolah inklusif dirasakan bukan hanya oleh ABK, namun juga oleh teman, guru, dan bahkan orangtua.

Dalam pelaksanaannya, para guru yang bekerja di sekolah inklusif mengalami banyak kesulitan, yaitu kurangnya dukungan, pelatihan, dan kurangnya waktu untuk berkolaborasi dengan para ahli, kesulitan dalam menghadapi perilaku siswa berkebutuhan khusus, dan kesulitan dalam mendesain dan mengimplementasikan instruksi yang sesuai (Salend, 2011) Selain itu, seringkali ABK menerima perlakuan yang negatif dari teman-teman sekelasnya. Penerimaan yang rendah oleh teman sekelasnya 
menyebabkan ABK rentan mengalami bullying, diabaikan, atau dijauhi (de Boer, Pijl, \& Minnaert, 2012). Tsang (2013) mengemukakan bahwa baik siswa berkebutuhan khusus maupun siswa reguler di sekolah inklusif sama-sama berjuang untuk memahami bagaimana cara untuk berinteraksi satu sama lain, yang sebelumnya masalah ini tidak disadari oleh para guru sebagai mediator di sekolah.

Sementara ABK harus berupaya mengatasi berbagai hambatan setiap hari, orangtua ABK juga menghadapi tantangan yang tidak mudah untuk dihadapi. Orangtua mungkin mengalami stigma disabilitas anak mereka dalam berbagai cara (Uba \& Nwoga 2016). Selain itu, terdapat banyak kekhawatiran yang dialami orangtua, yaitu mengenai kurikulum yang fungsional, kemampuan guru pada penyampaian instruksi yang berbeda kepada siswa reguler ataupun kepada siswa berkebutuhan khusus, serta pengarahan dan bantuan yang diberikan oleh tim ahli yang profesional (guru, psikolog, dokter,dll), juga kekhawatiran jika anak mereka terisolasi dari teman-teman sekelasnya dan menjadi target dari pelecehan melalui kata-kata yang dapat menurunkan kepercayaan diri anak-anak berkebutuhan khusus (Salend, 2011).

Meskipun menghadapi tantangan, orangtua memiliki harapan yang tinggi agar anak-anak mereka berhasil dan berkontribusi pada masyarakat (Wong, Meng, Kenneth Poon, Sarinajit,\& Jia Ng, 2014). Peran orangtua menjadi sangat penting dalam pendidikan inklusif, yaitu sebagai pembela anak mereka saat terjadi diskriminasi, dan sebagai pemberi informasi yang berharga mengenai kondisi anak mereka karena merekalah orang pertama yang mengenali kondisi anak mereka sebelum masuk ke dalam sekolah (Ferrel, 2012). Untuk memungkinkan adanya keterlibatan orang tua dalam pendidikan ABK, penting untuk memahami perspektif orang tua mengenai pendidikan anak-anak mereka (Swick \& Hooks, 2005). Perspektif orangtua dapat memfasilitasi parent-school partnership yang penting untuk keberhasilan dalam mengimplementasikan pendidikan inklusif (Lui, Sin, Yang, Forlin, \& Ho, 2015). Dengan demikian, sangat penting untuk meneliti perspektif orangtua terhadap anak berkebutuhan khusus di sekolah inklusif. Menurut Oxford Advanced American Dictionary (2019), perspektif bisa didefinisikan sebagai cara berpikir dan sikap tertentu tentang sesuatu, kemampuan untuk memikirkan masalah dan suatu keputusan dengan cara yang masuk akal tanpa membesar-besarkan kepentingannya, dalam hal ini yaitu mengenai anak berkebutuhan khusus di sekolah inklusif. 


\section{METODE}

\section{Kriteria Pencarian}

Artikel yang dimasukkan ke dalam penelitian ini adalah semua artikel yang membahas mengenai perspektif orangtua pada Anak Berkebutuhan Khusus (ABK) di sekolah inklusif. Orangtua yang termasuk dalam penelitian ini adalah orangtua yang memiliki Anak Berkebutuhan Khusus. Jenjang pendidikan yang dipilih adalah semua jenjang pendidikan mulai dari preschool hingga perguruan tinggi. Definisi operasional untuk Anak Berkebutuhan Khusus mengacu pada kriteria yang diatur dalam Permendiknas No. 70 tahun 2009 pasal 3 ayat 2, yaitu : tunanetra, tunarungu, tunawicara, tunagrahita, tunadaksa, tunalaras, berkesulitan belajar, lamban belajar, autis, memiliki gangguan motorik, menjadi korban penyalahgunaan narkoba, obat terlarang, dan zat adiktif lainnya, memiliki kelainan lainnya, dan tunaganda. Penelitian mengenai perspektif orangtua juga mencakup mengenai persepsi mereka mengenai program yang dijalankan di sekolah inklusif namun tidak memasukkan penelitian mengenai keterlibatan orangtua yang merupakan dampak dari perspektif orangtua terhadap sekolah inklusif.

\section{Prosedur Pencarian}

Prosedur pencarian melibatkan pencarian berbasis data komputer, pemilihan artikel yang lengkap, berbahasa Inggris, dan ditinjau ulang secara akademik. Artikel dijaring melalui database dari Scopus, dan Taylor \& Francis Online dengan memakai kata kunci kombinasi, seperti 'parent perspectives' AND ‘disability’ AND ‘inclusive education'. Kriteria tambahan yang dimasukkan adalah bahwa penelitian ini merupakan refereed journal.

Pencarian dilakukan terhadap artikel yang diterbitkan antara bulan Oktober 2010 hingga Oktober 2019. Setelah membaca setiap judul dari artikel, didapat total 1519 artikel. Artikel tersebut kemudian diseleksi dan dieliminasi melalui analisis berdasarkan: (1) identifikasi judul, nama peneliti, dan abstrak; (2) kelengkapan informasi mengenai tujuan penelitian, metode, dan hasil; (3) penilaian studi-studi yang akan diseleksi dan dieliminasi; (4) membuat keputusan pada studi-studi yang akan diseleksi dan dieliminasi. Setelah melalui proses seleksi, terdapat 1509 artikel yang tidak sesuai kriteria karena ketidaksesuaian pada topik dan isi penelitian dan terdapat 12 artikel yang dipertimbangkan untuk dapat dikaji lebih lanjut.

Setelah membaca lebih cermat 12 artikel tersebut, hanya 9 artikel yang diputuskan untuk digunakan dan 3 artikel lainnya dieliminasi dengan alasan: (1) satu studi merupakan studi literatur (2) satu studi merupakan penilaian mengenai pengaruh dari program intervensi yang dirancang sekolah, dan (3) tujuh studi tidak melaporkan hasil penelitian secara lengkap. 


\section{Ekstraksi Data}

Hasil pencarian melalui database menghasilkan total 9 artikel yang telah memenuhi kriteria dan dapat dianalisa lebih lanjut, yaitu SCOPUS [N = 2], dan Taylor \& Francis Online [N = 7]. Gambar 1 menjelaskan diagram alur dari proses menjaring dan menyeleksi artikel.

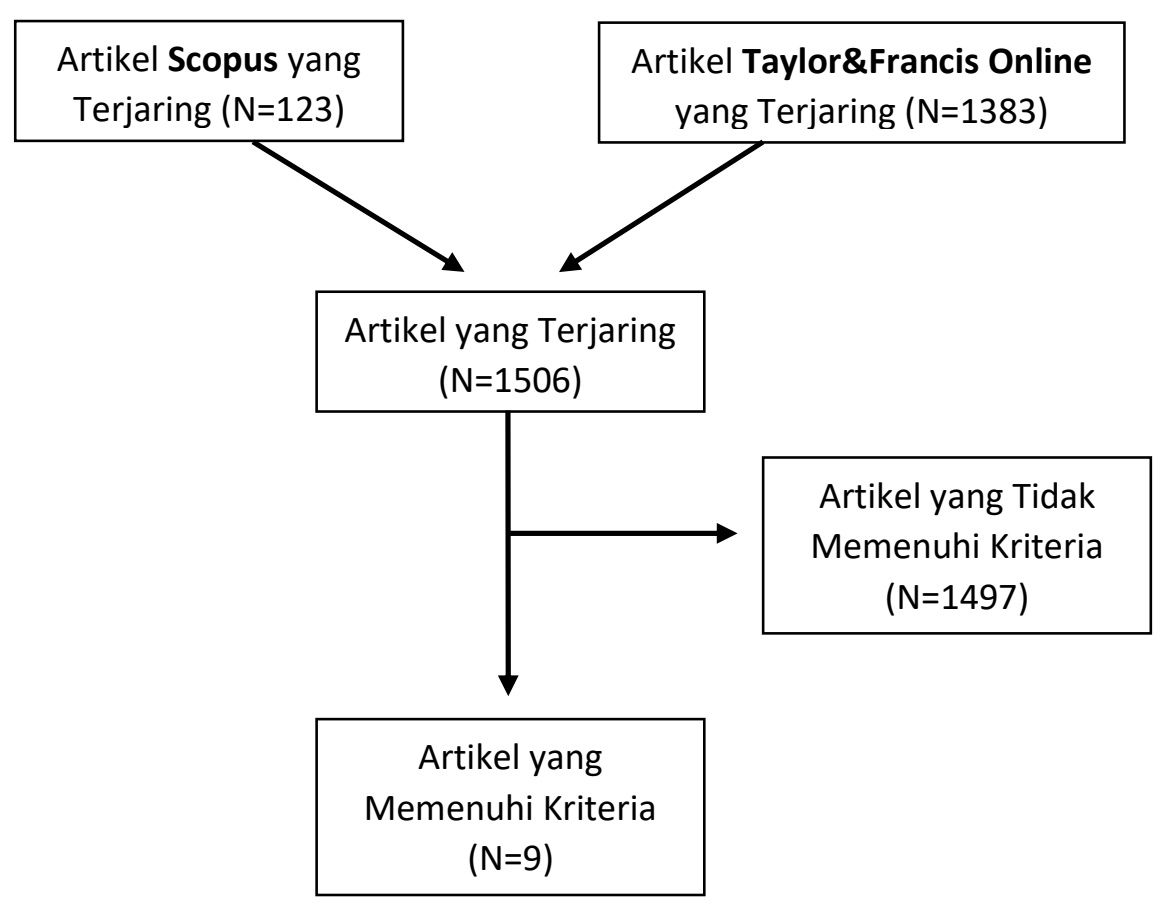

Gambar 1. Diagram alur dari proses menjaring dan menyeleksi artikel

\section{Karakteristik Partisipan}

Partisipan yang dipilih dalam artikel penelitian yaitu orangtua yang memiliki Anak Berkebutuhan Khusus (ABK). Jenjang pendidikan dari anak yang diteliti yaitu pre-school (Samadi \& McConkey,2018), sekolah dasar (Stevens \& Wurf, 2018; Magumise \& Sefotho, 2018), sekolah menengah atas (Jigyel, Miller, Mavropoulou, \& Berman, 2018), dan perguruan tinggi (Wong, Meng, Kenneth Poon, Sarinajit, \& Jia Ng, 2014). Sebagai tambahan, terdapat pula penelitian yang meneliti jenjang yang beragam dalam penelitiannya (Sharma \& Michael, 2017; Brydges \& Mkandawire, 2018; Rice, 2017; Tryfon, Anastasia, \& Eleni, 2019). 


\section{HASIL DAN PEMBAHASAN}

Sembilan studi penelitian yang telah memenuhi kriteria dijabarkan lebih lanjut melalui Tabel 1. Terdapat satu studi yang menggunakan metode kuantitatif (Tryfon, Anaastasia, \& Eleni, 2019), satu studi menggunakan metode feasibility study (Samadi \& McConkey, 2018), dan tujuh studi lainnya yang menggunakan metode kualitatif yang menggambarkan perspektif orangtua pada anak berkebutuhan khusus di sekolah inklusif.

Beberapa dari hasil temuan juga menjabarkan perspektif tambahan dari pihak lain selain orangtua, yaitu perspektif dari kepala sekolah (Samadi \& McConkey, 2018), guru (Magumise \& Sefotho, 2018), dan orangtua yang tidak memiliki anak berkebutuhan khusus (Stevens \& Wurf, 2018). Penelitian lainnya juga meneliti perspektif orangtua terhadap perbandingan antara special class, mainstream class with coteaching arrangement, dan mainstream class (Tryfon, Anaastasia, \& Eleni, 2019; Brydges \& Mkandawire, 2018).

\begin{tabular}{|c|c|c|c|c|}
\hline Studi, Negara & Partisipan & $\begin{array}{l}\text { Jenjang } \\
\text { Pendidikan ABK }\end{array}$ & $\begin{array}{l}\text { Metode / } \\
\text { Alat Ukur }\end{array}$ & $\begin{array}{l}\text { Perspektif Orangtua terhadap } \\
\text { Sekolah Inklusif }\end{array}$ \\
\hline $\begin{array}{l}\text { Sharma \& } \\
\text { Michael (2017), } \\
\text { Negara Pasifik }\end{array}$ & $\begin{array}{l}19 \text { orangtua } \\
\text { (16 ibu dan } 3 \\
\text { ayah) }\end{array}$ & Bera & $\begin{array}{l}\text { Kualitatif / } \\
\text { Semi } \\
\text { Structured } \\
\text { Interviews }\end{array}$ & $\begin{array}{l}\text { Mayoritas orangtua mendukung } \\
\text { adanya pendidikan inklusif, } \\
\text { namun orangtua menaruh } \\
\text { perhatian pada beberapa hal } \\
\text { dalam proses penyelenggaraan } \\
\text { pendidikan inklusif. }\end{array}$ \\
\hline $\begin{array}{l}\text { Brydges \& } \\
\text { Mkandawire } \\
\text { (2018), Nigeria }\end{array}$ & $\begin{array}{l}12 \text { orangtua } \\
\text { (10 ibu dan } 2 \\
\text { ayah) }\end{array}$ & Beragam & $\begin{array}{l}\text { Kualitiatif/ } \\
\text { Semi } \\
\text { Structured } \\
\text { Interviews }\end{array}$ & $\begin{array}{l}\text { Orangtua memiliki pandangan } \\
\text { yang berbeda mengenai } \\
\text { pendidikan inklusif, dengan } \\
\text { pemahaman yang jelas mengenai } \\
\text { keuntungan dan kerugian yang } \\
\text { dapat diterima oleh anak mereka. } \\
\text { Beberapa orangtua mendukung } \\
\text { dan beberapa orangtua lain } \\
\text { menganggap SLB adalah pilihan } \\
\text { terbaik bagi anak mereka. }\end{array}$ \\
\hline
\end{tabular}




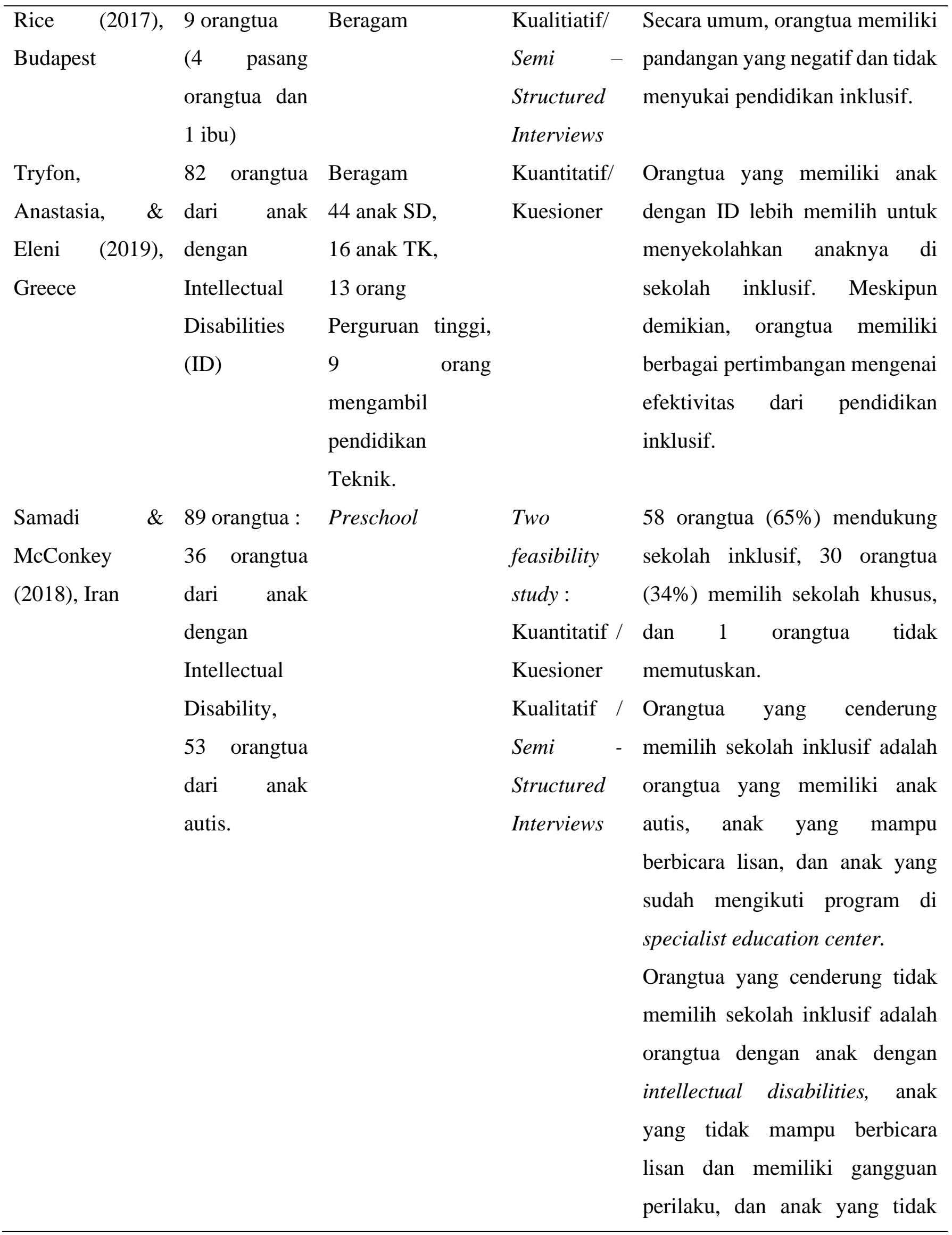


mendatangi specialist education

center.

Stevens \& Wurf 44 orangtua : Sekolah Dasar

(2018), Australia 8 orangtua

dari $\mathrm{ABK}$

36 orangtua

dari anak

reguler

Magumise \& 12 orangtua Sekolah Dasar

Sefotho (2018), dan 12 guru

Zimbabwe

Jigyel, Miller, 26 orangtua Sekolah

Mavropoulou, \& (13 ayah dan Menengah Atas

Berman (2018), $13 \mathrm{ibu})$

Bhutan
Kuantitatif / Orangtua sepakat bahwa

Kuesioner pendidikan inklusif bermanfaat bagi anak mereka. Orangtua ABK sangat setuju bahwa anak mereka memiliki hak untuk pendidikan inklusif.

Kualitatif / Persepsi orangtua dan guru Focus mengenai pendidikan inklusif Group menunjukkan hasil yang

Discussion bervariasi. Beberapa melihatnya $(F G D s)$ dan secara positif, beberapa menaruh interview. perhatian mengenai bagaimana memandang prinsip inklusif, keuntungan yang bisa didapat dan juga kekhawatiran mengenai kurangnya kesiapan dalam mengimplementasikan pendidikan inklusif di Zimbabwe dan negara berkembang lainnya. Kualitatif / Orangtua dari anak dengan Open-ended gangguan perkembangan interviews mengaitkan pendidikan inklusif dengan manfaat sosial yang bisa didapat. Orangtua dari anak dengan keterbatasan fisik mengaitkan pendidikan inklusif dengan adanya perhatian dan lingkungan yang suportif sebagai keuntungan utama. Sebagian besar orangtua merasa puas 
dengan sekolah inklusif tempat

anak mereka bersekolah

meskipun sekolah memiliki

keterbatasan dan orangtua

memiliki kekhawatiran.

Wong, Poon, 13 orangtua Perguruan Tinggi Kualitatif / Perspektif orangtua mengenai Kaur, \& Jia Ng yang (2014), memiliki

Singapore anak dengan

mild

disabilities.
Semi - pendidikan inklusif tidak hanya Structured mengenai dukungan yang bisa Interviews diberikan oleh sekolah namun juga kekhawatiran yang lebih dalam tentang apakah $\mathrm{ABK}$ dapat berkontribusi dalam masyarakat. Mengingat bahwa pencapaian akademis dan sosial adalah syarat penting untuk dapat masuk dalam komunitas masyarakat, orangtua menaruh perhatian pada seberapa besar tingkat kesulitan dan tekanan yang sesuai untuk bisa mengerahkan diri ABK, sekolah, dan pribadi orangtua ketika memperjuangkan pendidikan inklusif bagi anak mereka.

Terdapat kesamaan dalam topik pembahasan dari studi penelitian yang menjabarkan perspektif orangtua pada anak berkebutuhan khusus di sekolah inklusif yang kemudian dikelompokkan menjadi empat tema besar, yaitu sekolah, masyarakat, pemerintah, dan keluarga. Hasil temuan pada berbagai tema tersebut dijabarkan pada Tabel 2. Tema-tema di bawah ini tidak berdiri sendiri dan saling berkaitan satu sama lain sepanjang peneliti menjabarkan mengenai pendidikan inklusif. Tema-tema ini mewakili keprihatinan, perhatian, pengalaman, dan saran dari orangtua selama menyekolakan Anak Berkebutuhan Khusus di sekolah inklusif. 


\section{Tabel 2. Kajian Hasil Temuan Berdasarkan Tema}

\begin{tabular}{ll}
\hline Tema & Hasil Temuan \\
\hline Sekolah & Positif
\end{tabular}

1. Sekolah inklusif dapat membantu ABK mencapai nilai akademik yang lebih baik.

2. Jika bersekolah di SLB, ABK hanya akan berteman dengan sesama ABK lain dan hal ini akan merugikan ketika ia harus pergi dan berada dalam kelompok masyarakat yang lebih luas.

3. Terdapat perubahan positif ABK pada segi akademik dan non-akademik.

4. Terlepas dari tingkat gangguan Intellectual Disability (ID) pada anak-anak mereka, mayoritas orangtua menginginkan anak mereka untuk berada dalam sekolah inklusif dengan adanya co-teaching arrangement.

5. Orangtua dari anak dengan ID ringan percaya bahwa pendidikan inklusif dapat membantu pencapaian akademik dan relasi sosial yang lebih baik.

6. Sekolah inklusif dapat memberikan pengalaman "kehidupan nyata" bagi anak dan membantu anak untuk meregulasi diri dan mengurangi perilaku agresif.

7. Staf pengajar yang suportif merupakan hal yang fundamental bagi keberhasilan pendidikan inklusif.

8. Sekolah inklusif dapat meningkatkan kemampuan merawat diri dan kemandirian pada $\mathrm{ABK}$.

9. Sekolah inklusif juga dapat meningkatkan kemampuan mobilitas dan perkembangan bicara anak.

10. Kepuasan orangtua terkait dengan dukungan yang mereka terima dari sekolah dan keterlibatan dari anak mereka. Jika anak tidak sekolah akan membuat stres bagi orangtua dan membosankan untuk anak.

\section{Negatif}

1. Kurangnya kesiapan guru dalam mengajar ABK.

2. Kurangnya pelatihan tentang pendidikan inklusif untuk guru.

3. Sekolah perlu membangun sistem kolaborasi dengan keluarga untuk membuat kurikulum yang sesuai untuk ABK.

4. Orangtua yang menyekolahkan anaknya di SLB menganggap di sekolah ini ABK mendapatkan dukungan yang lebih profesional dan menganggap bahwa sekolah inklusif tidak bisa memenuhi kebutuhan spesifik dari ABK. 
5. Sekolah inklusif tidak menerima semua jenis disabilitas karena kebanyakan sekolah tidak memiliki guru khusus untuk dapat menangani jenis disabilitas tertentu.

6. Tingkat gangguan dari jenis disabilitas, dan seberapa besar upaya yang diperlukan sekolah untuk menangani ABK memiliki pengaruh besar pada bagaimana orangtua memilih sekolah.

7. ABK tidak diberikan kesempatan yang sama untuk bisa berhasil dalam sekolah inklusif kecuali ABK menerima akomodasi dan fasilitas yang dapat membantu mereka dalam proses belajar yang juga istimewa.

8. Sekolah inklusi sudah ketinggalan jaman dalam hal material, metode pengajaran, dan dukungan untuk $\mathrm{ABK}$.

9. Guru tidak memberikan arahan yang berbeda kepada ABK saat mengajar. Guru juga tidak memberikan metode pengajaran yang dapat menarik dan dipahami oleh anak.

10. Orangtua dari anak dengan ID sedang dan berat menilai efektivitas dari pendidikan inklusif pada kategori sedang dan rendah.

11. Kepala sekolah berpendapat orangtua dari anak reguler tidak senang saat ABK duduk di dekat anak mereka, takut jika anaknya akan belajar berperilaku aneh, dan cenderung menyalahkan ABK jika terdapat perilaku buruk dari anak reguler.

12. Guru terkadang bersikap tidak konsisten dalam mengimplementasikan sikap disiplin pada anak.

\section{Masyarakat Positif}

1. Sekolah inklusif akan membantu ABK untuk dapat beradaptasi dalam kelompok masyarakat.

2. ABK menjadi lebih percaya diri saat menjalin hubungan dengan teman-temannya.

3. Orangtua senang saat anak reguler dan disabilitas dapat belajar bagaimana saling berinteraksi dengan berbagai latar belakang.

4. Adanya pengaruh positif dari anak reguler, terutama jika mereka memiliki minat yang sama.

Negatif 
1. Sikap negatif, stigma, dan cultural beliefs dari lingkungan sosial merupakan alasan para orangtua memutuskan untuk tidak menyekolahkan anaknya dan memutuskan untuk menjaga anaknya di rumah

2. ABK hampir tidak memiliki teman.

3. Sebagian besar memilih berada di dalam ruangan ketika lingkungan sosial menghindar untuk berinteraksi.

4. Tertolak dan menarik diri untuk ikut berpartisipasi dalam aktivitas.

5. ABK mengalami bullying tidak hanya dalam lingkungan sekolah, masyarakat, bahkan di lingkungan keluarga.

6. Adanya diskriminasi bagi $\mathrm{ABK}$

7. Kurangnya empati

\section{Pemerintah Positif}

Tidak ditemukan perspektif positif orangtua mengenai upaya yang telah dilakukan pemerintah terhadap pendidikan inklusif.

\section{Negatif}

1. Kurangnya pengetahuan dan ketersediaan informasi mengenai program untuk mengidentifikasi ABK (intervensi dini).

2. Kurangnya dukungan dari badan pemerintah terhadap pendidikan inklusif.

3. Sebagian besar dukungan berasal dari organisasi swasta dan berbasis agama.

4. Pemerintah tidak memberikan dukungan finansial yang memadai terhadap penyediaan alat bantu untuk ABK.

5. Meskipun sudah tercantum dalam Undang-Undang, namun sebagian ABK tidak dapat masuk ke sekolah umum karena ketidaktersediaan fasilitas dan alat bantu yang diperlukan.

6. Mengurangi stigma dan sikap negatif terhadap ABK tidak bisa hanya dilakukan dan difokuskan pada kebijakan sekolah inklusif karena memiliki efek yang terbatas, namun perlu juga mempromosikan prinsip kesetaraan dan keadilan sosial bagi ABK dengan adanya perubahan sosial dan budaya yang menyeluruh.

7. Letak geografis sekolah mempengaruhi dukungan yang dapat diterima. Sekolah yang berada di wilayah perkotaan mendapatkan akses yang lebih mudah untuk mendapat dukungan medis dan terapi, hal sebaliknya terjadi pada sekolah di wilayah pedesaan. 
Peran

Keluarga
1. Orangtua perlu terlibat dalam mengambil keputusan karena memiliki pengetahuan mengenai anak mereka.

2. Orangtua membutuhkan pelatihan, dukungan, dan pemberdayaan untuk mengatasi paradigma masyarakat mengenai ABK.

3. Orangtua harus terlibat aktif untuk dapat mendukung hak ABK dalam menerima pendidikan.

4. Beberapa orangtua memahami bahwa jika ABK tidak mampu mengatasi tantangan yang ada di sekolah inklusif, mereka tidak memiliki pilihan selain memasukkan anak mereka ke SLB.

5. Ibu secara khusus, sering dianggap sebagai pengasuh utama $A B K$, dan sering disalahkan oleh pasangan atau keluarga saat melahirkan anak dengan kebutuhan khusus. Kesulitan dan tantangan yang dihadapi, cenderung harus mengurus ABK sendirian dan banyaknya waktu yang harus dihabiskan untuk merawat $\mathrm{ABK}$ mungkin akan menghambat ibu untuk mengembangkan potensi diri, bekerja, mendapatkan penghasilan, atau kegiatan yang diperlukan untuk kesejahteraan diri mereka sendiri.

6. Sebagian besar orangtua dari anak dengan ID merasa tingkat keterlibatan dengan guru berada di kategori sedang atau kurang.

7. Orangtua dari anak reguler memiliki sikap yang lebih negatif pada pendidikan inklusif daripada orangtua $\mathrm{ABK}$.

8. Orangtua yang memiliki pengetahuan luas akan bersikeras mengenai jenis dan tingkat dukungan yang diberikan sekolah. Mereka akan memiliki dorongan yang kuat untuk menciptakan peluang dan menghilangkan hambatan yang anak mereka alami sehingga menciptakan ketegangan dalam home-school partnership. Sedangkan orangtua yang memiliki pengetahuan yang sempit cenderung tunduk dan menyetujui keputusan-keputusan mengenai pendidikan anak mereka dan memiliki harapan yang minimal terhadap dukungan sekolah.

9. Orangtua yang memiliki ambisi terhadap pendidikan akan melihat pendidikan inklusif sebagai kesempatan untuk mengembangkan potensi anak dan mendukung perkembangan sosial. Orangtua juga cenderung menekankan "normalitas" pada anak mereka, dan terkadang berharap bahwa keterbatasan anak mereka dapat sembuh secara ajaib. Sebaliknya, orangtua yang mengenali dan sudah menerima 
keterbatasan dari anak mereka akan menyadari keterbatasan anak mereka, berupaya yang terbaik untuk lulus ujian dan akan bangga dengan semua prestasi yang dapat dicapai anak. Mereka cenderung mengabaikan ekspektasi pada anak karena takut akan adanya tekanan yang tidak semestinya mereka berikan pada diri sendiri dan potensi kekecewaan ketika target tidak tercapai. Persepsi orangtua tentang disabilitas anak mereka yang menghalangi mereka untuk membayangkan masa depan yang positif.

10. Meskipun memerlukan biaya yang sangat tinggi dalam mendukung anak disabilitas, orangtua secara aktif mencari bantuan di luar sekolah untuk meningkatkan kompetensi akademik dan sosial anak mereka.

\section{Diskusi}

Dari sembilan artikel dalam kajian literatur, peneliti menemukan bahwa mayoritas orangtua dari ABK memiliki perspektif yang positif mengenai pendidikan inklusif, terutama orangtua yang memiliki anak Intellectual Disability (Tryfon, Anaastasia, \& Eleni, 2019). Meskipun demikian, nampaknya perspektif orangtua dari anak ID terhadap pendidikan inklusif masih lebih rendah daripada orangtua dari anak autis, anak yang sudah mampu berbicara lisan, dan anak yang sudah mengikuti program di specialist education center (Samadi \& McConkey, 2018). Hasil penelitian juga mengungkapkan bahwa jumlah orangtua yang mendukung dan memilih untuk menyekolahkan anaknya di sekolah inklusif lebih banyak daripada orangtua yang memilih Sekolah Luar Biasa (Samadi \& McConkey, 2018). Hanya terdapat satu penelitian yang menyatakan bahwa secara umum orangtua memiliki pandangan negatif dan tidak menyukai pendidikan inklusif (Rice, 2017).

Pembahasan dalam kajian literatur ini difokuskan untuk tidak sekedar memahami apakah orangtua dari ABK memiliki perspektif yang positif atau negatif terhadap pendidikan inklusif, namun juga menguraikan tema-tema penting yang menjadi perhatian, kekhawatiran, dan harapan orangtua, serta masukan orangtua mengenai hal-hal yang masih perlu ditingkatkan dalam mengimplementasikan pendidikan inklusif. Pertama, mengenai sekolah. Orangtua setuju dan mengungkapkan bahwa pendidikan inklusif dapat memberikan keuntungan positif bagi $A B K$, yaitu dapat membantu ABK untuk mencapai nilai akademik dan relasi sosial yang lebih baik, dapat meningkatkan kemampuan mobilitas, kemandirian, dan perkembangan bicara, memberikan pengalaman yang nyata bagi ABK dalam berelasi dengan anak reguler serta membantu anak untuk bisa meregulasi diri dengan lebih baik. Kesempatan 
untuk memiliki pengalaman dalam berelasi sosial dengan anak reguler mungkin tidak akan didapat jika anak berada dalam Sekolah Luar Biasa (SLB) dan hal ini akan merugikan ABK ketika suatu saat ia harus pergi dan berada dalam kelompok masyarakat yang lebih luas (Brydges \& Mkandawire, 2018).

Meskipun orangtua memandang bahwa sekolah inklusif dapat memberikan dampak yang positif bagi $\mathrm{ABK}$, terdapat pula perhatian yang diberikan orangtua kepada pihak sekolah terkait bagaimana pendidikan inklusif dapat diimplementasikan dengan baik. Orangtua melihat bahwa masih kurangnya pelatihan untuk guru mengenai cara mengajar dalam setting inklusif sehingga guru terlihat kurang siap dalam menerima dan mengajar ABK (Sharma \& Michael, 2017), guru tidak memberikan arahan yang berbeda dan metode pengajaran yang dapat dipahami ABK (Rice, 2017), dan terkadang tidak konsisten dalam mengimplementasikan sikap disiplin. Orangtua juga menilai bahwa sekolah belum menyediakan sarana dan prasarana yang dapat mendukung ABK dalam kegiatan belajar, sekolah dinilai sudah ketinggalan zaman dalam hal material, metode pengajaran, dan dukungan untuk ABK (Rice, 2017). Sekolah inklusif juga tidak menerima semua jenis disabilitas karena kebanyakan sekolah tidak memiliki guru khusus untuk dapat menangani jenis disabilitas tertentu (Brydges \& Mkandawire, 2018). Jika membandingkannya dengan SLB, orangtua menilai bahwa SLB memiliki sarana dan prasarana yang lebih memadai, dan adanya dukungan dari para profesional untuk memenuhi kebutuhan spesifik dari ABK (Brydges \& Mkandawire, 2018). Terdapat tambahan perspektif dari kepala sekolah yang berpendapat bahwa orangtua dari anak reguler tidak senang saat ABK duduk di dekat anak mereka, takut jika anaknya akan belajar berperilaku aneh, dan cenderung menyalahkan ABK jika terdapat perilaku buruk dari anak reguler (Samadi \& McConkey, 2018). Pada akhirnya orangtua menilai bahwa sekolah perlu membangun sistem kolaborasi dengan keluarga untuk membuat kurikulum yang sesuai untuk ABK (Sharma \& Michael, 2017).

Kedua, mengenai masyarakat. Orangtua menilai bahwa sekolah inklusif akan membantu ABK untuk dapat beradaptasi dalam kelompok masyarakat. Kesempatan untuk bertemu dan berelasi dengan anak reguler akan membuat $\mathrm{ABK}$ lebih percaya diri dan anak reguler dapat memberikan pengaruh positif bagi ABK, terutama jika mereka memiliki minat yang sama. Meskipun demikian, masih banyaknya sikap negatif, stigma, dan cultural beliefs dari lingkungan sosial yang membuat orangtua memutuskan untuk tidak menyekolahkan anaknya dan memutuskan untuk menjaga anaknya di rumah (Sharma \& Michael, 2017). ABK juga merasa tertolak, merasa hampir tidak memiliki teman, dan memilih menarik diri dari aktivitas serta memilih berada di dalam ruangan ketika lingkungan sosial menghindar untuk berinteraksi (Sharma \& Michael, 2017). ABK juga mengalami bullying dan diskriminasi, tidak hanya dialami di 
dalam lingkungan sekolah, masyarakat, bahkan di lingkungan keluarga (Brydges \& Mkandawire, 2018; Rice, 2017). Mengurangi stigma dan sikap negatif terhadap ABK tidak bisa hanya dilakukan dan difokuskan pada kebijakan sekolah inklusif karena memiliki efek yang terbatas, yaitu hanya difokuskan kepada orang-orang yang berada di lingkungan sekolah. Perlu ada upaya untuk mempromosikan prinsip kesetaraan dan keadilan sosial bagi ABK tidak hanya di lingkungan sekolah, namun juga kepada masyarakat yang lebih luas yang akan diuraikan lebih spesifik dalam tema yang ketiga, yaitu pemerintah.

Orangtua menilai kurangnya dukungan dari badan pemerintah terhadap pendidikan inklusif. Sebagian besar dukungan yang berasal dari organisasi swasta dan berbasis agama serta pemerintah tidak memberikan dukungan finansial yang memadai terhadap penyediaan alat bantu untuk ABK (Sharma \& Michael, 2017). Meskipun sudah tercantum dalam Undang-Undang, namun sebagian ABK tidak dapat masuk ke sekolah regular karena ketidaktersediaan fasilitas dan alat bantu yang diperlukan. Selain itu, letak geografis sekolah mempengaruhi dukungan yang dapat diterima. Sekolah yang berada di wilayah perkotaan mendapatkan akses yang lebih mudah untuk mendapat dukungan medis dan terapi, hal sebaliknya terjadi pada sekolah di wilayah pedesaan. Orangtua juga menaruh perhatian khusus kepada pemerintah mengenai kurangnya pengetahuan dan ketersediaan informasi mengenai program untuk mengidentifikasi ABK (intervensi dini).

Hal terakhir namun merupakan yang terpenting, yaitu peran orangtua. Dari hasil penelitian diketahui bahwa orangtua dari anak reguler memiliki sikap yang lebih negatif pada pendidikan inklusif daripada orangtua ABK. Selain itu, ibu secara khusus, sering dianggap sebagai pengasuh utama ABK, dan sering disalahkan oleh pasangan atau keluarga saat melahirkan anak dengan kebutuhan khusus. Kesulitan dan tantangan yang dihadapi, cenderung harus mengurus ABK sendirian dan banyaknya waktu yang harus dihabiskan untuk merawat ABK mungkin akan menghambat ibu untuk mengembangkan potensi diri, bekerja, mendapatkan penghasilan, atau kegiatan yang diperlukan untuk kesejahteraan diri mereka sendiri (Brydges \& Mkandawire, 2018). Orangtua menilai bahwa mereka membutuhkan pelatihan, dukungan, dan pemberdayaan untuk mengatasi paradigma masyarakat mengenai ABK.

Selain itu, orangtua, baik ayah maupun ibu perlu terlibat dalam mengambil keputusan karena memiliki pengetahuan mengenai anak mereka dan harus terlibat aktif untuk dapat mendukung hak ABK dalam menerima pendidikan. Sebagian besar orangtua dari anak dengan ID merasa tingkat keterlibatan dengan guru berada di kategori sedang atau kurang (Tryfon, Anaastasia, \& Eleni, 2019). Beberapa orangtua memahami bahwa jika ABK tidak mampu mengatasi tantangan yang ada di sekolah inklusif, mereka tidak memiliki pilihan selain memasukkan anak mereka ke SLB. Orangtua yang memiliki 
pengetahuan luas akan memiliki dorongan yang kuat untuk menciptakan peluang dan menghilangkan hambatan yang anak mereka alami sehingga menciptakan ketegangan dalam home-school partnership. Sedangkan orangtua yang memiliki pengetahuan yang sempit cenderung tunduk dan menyetujui keputusan-keputusan mengenai pendidikan anak mereka dan memiliki harapan yang minimal terhadap dukungan sekolah. Orangtua yang memiliki ambisi terhadap pendidikan akan melihat pendidikan inklusif sebagai kesempatan untuk mengembangkan potensi anak dan mendukung perkembangan sosial. Sebaliknya, orangtua yang mengenali dan sudah menerima keterbatasan dari anak mereka akan menyadari keterbatasan anak mereka, berupaya yang terbaik untuk lulus ujian dan akan bangga dengan semua prestasi yang dapat dicapai anak. Mereka cenderung mengabaikan ekspektasi pada anak karena takut akan adanya tekanan yang tidak semestinya mereka berikan pada diri sendiri dan potensi kekecewaan ketika target tidak tercapai. Persepsi orangtua tentang disabilitas anak mereka yang menghalangi mereka untuk membayangkan masa depan yang positif (Wong, Poon, Kaur, \& Jia Ng, 2014).

\section{Batasan Penelitian}

Artikel yang memenuhi kriteria dalam studi literatur mengenai perspektif orangtua pada anak berkebutuhan khusus di sekolah inklusif sebagian besar menggunakan metode kualitatif. Metode ini dapat membantu peneliti untuk mendapatkan pemahaman secara mendalam, namun kekurangannya adalah jumlah sampel yang sedikit dari penelitian yang dilakukan menjadikan hasil kurang dapat digeneralisasikan. Selain itu, terdapat artikel yang tidak menyertakan kelengkapan data partisipan seperti usia partisipan, jenjang pendidikan, jenis disabilitas, dan karakteristik demografik sehingga sulit untuk menggeneralisasi hasil temuan atau mengidentifikasi faktor yang dapat mempengaruhi hasil penelitian. Keterbatasan lainnya yang ditemukan adalah jumlah partisipan ibu lebih banyak daripada ayah. Jenis kelamin juga akan mempengaruhi bagaimana perspektif yang mereka miliki.

Mengacu pada batasan penelitian yang telah diuraikan di atas, maka penelitian selanjutnya dapat dilakukan dengan memperhatikan metode penelitian dan faktor-faktor yang mempengaruhi perspektif orangtua pada anak berkebutuhan khusus di sekolah inklusif. Di samping keterbatasan tersebut, literature review ini telah memberikan gambaran sekilas baik secara kuantitatif maupun kualitatif terkait perspektif orangtua pada anak berkebutuhan khusus di sekolah inklusif. 


\section{SIMPULAN DAN SARAN}

Walaupun sebagian besar orangtua mendukung adanya pendidikan inklusif, namun masih terdapat banyak hambatan dan perhatian yang dimiliki orangtua terhadap pengimplementasian pendidikan inklusif secara maksimal. Pada tema sekolah, orangtua menaruh perhatian pada fasilitas yang bisa didapatkan, kurikulum yang tepat, kesiapan dan pelatihan untuk guru, dan sistem kolaborasi dengan orangtua. Pada tema masyarakat, orangtua menaruh perhatian besar terhadap banyaknya stigma dan sikap negatif terhadap anak berkebutuhan khusus dan mempengaruhi bagaimana mereka memperlakukan ABK, seperti sikap untuk menjauhi, kurangnya empati, dan bullying. Pada tema pemerintah, orangtua menaruh perhatian pada kurangnya informasi yang bisa didapatkan untuk memberikan intervensi yang tepat bagi $\mathrm{ABK}$, dan kurangnya program yang dibuat pemerintah untuk mendukung pendidikan inklusif. Pada tema peran keluarga, orangtua menyadari pentingnya keterlibatan orangtua terhadap pendidikan inklusif. Orangtua, terutama ibu, juga membutuhkan pelatihan, dukungan, dan pemberdayaan untuk mengatasi paradigma masyarakat mengenai ABK. 


\section{DAFTAR PUSTAKA}

Brydges, C., \& Mkandawire, P. 2018. Perceptions and experiences of inclusive education among parents of children with disabilities in Lagos, Nigeria. International Journal of Inclusive Education. https://doi.org/10.1080/13603116.2018.1480669

de Boer, A. Pijl, S. \& Minnaert, A. 2012. Students' attitudes towards peers with disabilities: A review of the literature. International Journal of Disability, Development and Education, 59(4), 379392.

Departemen Pendidikan Nasional. 2009. Undang-Undang Nomor 70 Tahun 2009, Tentang Pendidikan inklusif bagi Peserta Didik yang memiliki Kelainan dan Memiliki Potensi Kecerdasan dan/atau Bakat Istimewa, Jakarta: Depdiknas

Ferrel, J. 2012. Family engagement and children with disabilities : A resource guide for educators and parents. Cambrige, MA : Harvard Family Research Project.

Hamilton, A. 2013. Missy Hamilnook Reflects on Early Childhood Education. Parker, CO: Bookcrafters.

Jigyel, K., Miller, J. A., Mavropoulou, S., \& Berman, J. (2018). Benefits and concern: Parent's perceptions of inclusive schooling for children with special educational needs (SEN) in Bhutan. International Journal of Inclusive Education. Doi: 10.1080/13603116.2018.1511761

Lindsay, G. 2003. Inclusive education: A critical perspective. British Journal of Special Education, 30, 3-12.

Lui, M., Sin, K. F., Yang, L., Forlin, C., \& Ho, F. C. 2015. Knowledge and perceived social norm predict parents' attitudes towards inclusive education. International Journal of Inclusive Education, 19, $1-16$.

Magumise, J., \& Sefotho, M., M. 2018. Parent and teacher perceptions of inclusive education in Zimbabwe. International Journal of Inclusive Education. Doi: 10.1080/13603116.2018.1468497

Rice, N. 2017. Parent perspectives on inclusive education in Budapest. European Journal of Special Needs Education, 33(5), 723-733.

Rose, R., Shevlin, M., Twomey, M., \& Zhao, Y. 2017. Gaining access to support for children with special educational needs in the early years in Ireland: Parental perspectives. International Journal of Early Years Education, 25(4), 379-392.

Ruijs, N., Peetsma, T., \& van der Veen, I. 2010. The presence of several students with special educational needs in inclusive education and the functioning of students with special educational needs. Educational Review, 62, 1-37.

Sanders, M. G. \& Sheldon, S. B. 2009. Principals matter: A guide to school, family, and community partnerships. Corwin: A SAGE Company 
Samadi, S. A., \& McConkey., R. 2018. Perspectives on inclusive education of preschool children with autism spectrum disorder and other developmental disabilities in Iran. International Journal of Environmental Research and Public Health 15, 2307. Doi: 10.3390/ijerph15102307

Salend, S. J. 2011. Creating inclusive classrooms: Effective and reflective practices ( $7^{\text {th }}$ ed.). Boston: Pearson.

Sharma, U., \& Michael, S. 2017. Parental perspective about inclusive education in the Pacific. International Perspectives on Inclusive Education, 10, 71-86. https://doi.org/10.1108/S1479363620170000010010

Stevens, L., \& Wurf, G. 2018. Perceptions of inclusive education: A mixed methods investigation of parental attitudes in three Australian primary schools. International Journal of Inclusive Education. doi: 10.1080/13603116.2018.1464068

Swick, K. J., \& L. Hooks. 2005. Parental experiences and beliefs regarding inclusive placements of their special needs children.” Early Childhood Education Journal, 32(6), 397-402.

Tryfon, M., Anastasia, A., \& Eleni, R. 2019. Parental perspectives on inclusive education for children with intellectual disabilities in Greece." International Journal of Developmental Disabilities. Doi: 10.1080/20473869.2019.1675429

Tsang, K. L. V. 2013. Secondary pupils' perceptions and experiences toward studying in an inclusive classroom. International Journal of Whole Schooling, 9(2), 39-60.

Uba, C. D., \& Nwoga, K. A. 2016. Understanding stigma from a sociocultural context: Mothers' experience of stigma directed towards children with special educational needs. International Journal of Inclusive Education, 20(9), 975-994.

United Nations Educational, Scientific and Cultural Organization (UNESCO). 1994. The Salamanca Statement and Framework for Action on Special Needs Education. Paris: UNESCO.

Wiener, J., \& Tardif, C. Y. 2004. Social and emotional functioning of children with learning disabilities: Does special education placement make a difference? Learning Disabilities Research \& Practice, $19,20-32$.

Wong, M., Poon, K. K., Kaur, S., \& Jia Ng, Z. 2014. Parental perspectives and challenges in inclusive education in Singapore. Asia Pacific Journal of Education, 35(1), 85-97. Doi: 10.1080/02188791.2013.878309 